\title{
MASS BALANCE OF THE WARD HUNT ICE RISE AND ICE SHELF: A IO YEAR RECORD
}

\author{
By G. Hattersley-Smith and H. Serson \\ (Defence Research Establishment Ottawa, Ottawa 4, Ontario, Canada)
}

\begin{abstract}
The results of ro years' (1958-68) record of accumulation and ablation from the Ward Hunt ice rise and of 3 years' $(1965-68)$ record from the Ward Hunt Ice Shelf are presented. The net mass balances on the ice rise for the 3 years $1962-65$ are positive, while the net mass balances measured in the other years on both ice rise and ice shelf are all negative.

RÉsumé. Bilan de masse du dome de glace de Ward Hunt et de Ward Hunt Ice Shelf: Io ans de résultats. On présente les résultats de 10 ans ( $1958-68$ ) d'observations de l'accumulation et de l'ablation sur le dôme de glace de Ward Hunt et de trois années (1965-68) sur la Ward Hunt Ice Shelf. Le bilan net du dôme de glace pour les trois années $1962-65$ est positif, tandis que les bilans nets mesurés les autres années tant sur le dôme que sur la
platefoeme de glace sont tous négatifs.

Zusammenfassung. Massenbilanz der Ward-Hunt-Eisaufwölbung und des Ward Hunt Ice Shelf: eine Io-JahreUbersicht. Die Ergebnisse 1o-jähriger Beobachtungen (1958-68) der Akkumulation und der Ablation an der Ward-Hunt-Eisaufwölbung und 3-jähriger Beobachtungen (rg65-68) am Ward Hunt Ice Shelf werden vorgelegt. Die Netto-Massenbilanzen der Eisaufwölbung sind für die 3 Jahre $1962-65$ positiv, während die Netto-Massenbilanzen aller anderen Jahre sowohl für die Eisaufwölbung wie für das Eisschelf negativ sind.
\end{abstract}

\section{INTRODUCTION}

Since the recognition in $195^{\circ}$ that ice shelves occur off the north coast of Ellesmere Island (Koenig and others, I952), there has been speculation on whether they should be considered as relict features or as essentially the product of present climatic conditions. Field work in 1953-54 showed that the Ward Hunt Ice Shelf in its most recent history has undergone a long period of net ablation (Hattersley-Smith and others, I 955). This was evident from the heavy concentration of wind-blown dust at the surface and from the discovery of debris resting on the ice from one of R. E. Peary's overnight camps of 1906, since when there had evidently been no net accumulation. Both the Ward Hunt Ice Shelf and the ice rise showed considerable net surface ablation for the budget year I953-54; at one pole on the ice shelf this amounted to as much as $630 \mathrm{~mm}$ water. In the four summers from 1955 to $195^{8}$ the total net ablation on the ice shelf amounted to more than I $35^{\circ} \mathrm{mm}$ water (Crary, 1959). Further work on the ice shelf and ice rise showed net surface ablation of from 70 to $200 \mathrm{~mm}$ water in both the $195^{8-59}$ and I959-6o budget years (Lotz, I96I ; Lister, I962; Sagar, I962). In the winter of I961-62 massive calving reduced the area of the Ward Hunt Ice Shelf by about $600 \mathrm{~km}^{2}$; a strip of the ice shelf up to $8 \mathrm{~km}$ wide had moved to sea along a line back to the northern edge of the Ward Hunt ice rise (Hattersley-Smith, I 963). The part of the ice shelf where the r 959-6o observations had been made was removed, but the I959-6o grid of poles on the Ward Hunt ice rise was unaffected (Fig. I).

Since 1963 we have continued to make accumulation and ablation measurements each spring at the original poles on the ice rise, nearly all of which are still standing, and since I 966 we have made similar measurements at a $0.9 \mathrm{~km}$ square grid of $\mathrm{I}$ oo poles that were set in the ice shelf, $5 \mathrm{~km}$ east of Ward Hunt Island, in $\mathrm{I}_{96} 5^{-66}$ (Fig. I). In this paper the results of Io $^{-6}$ years' (I 958-68) records on the ice rise and 3 years' ( $1965^{-68)}$ records on the ice shelf are analysed.

\section{Field DATA}

The results of the measurements at 42 poles on the ice rise and at 100 poles on the ice shelf between $1_{96}{ }_{3}$ and 1969 , together with data from 45 poles on the ice rise for $1959-60$, are shown in Tables I and II. In each table the ranges and the means of total annual accumulation and of net annual accumulation or ablation at the various poles are shown. For the years 
1960-62 there are figures only for the combined net ablation for the 2 years, and there are no figures for the $1965-66$ accumulation. The ice shelf is characterized by a system of parallel surface ridges and troughs (Hattersley-Smith, 1957) and in Table II results from ridge poles are distinguished from those from trough poles in separate columns.

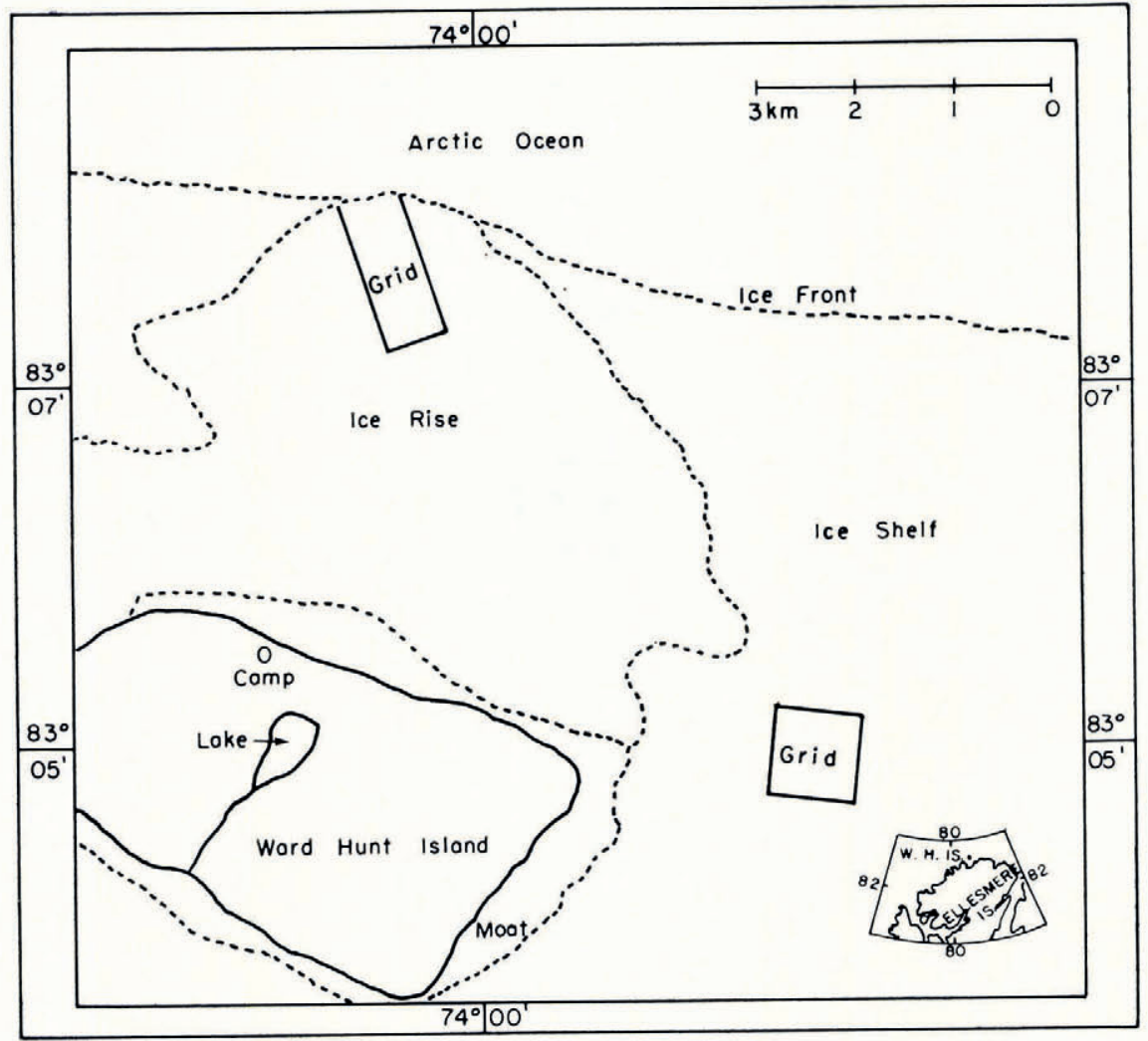

Fig. I. Map of Ward Hunt Island and adjacent ice rise and ice shelf.

Table I. Accumulation and ablation on the Ward Hunt ice Rise

\begin{tabular}{|c|c|c|c|c|c|c|c|c|}
\hline \multirow[b]{2}{*}{ Summer } & \multirow[b]{2}{*}{$\begin{array}{l}\text { Number of } \\
\text { poles }\end{array}$} & \multicolumn{4}{|c|}{ Accumulation } & \multicolumn{3}{|c|}{$\begin{array}{l}\text { Net ablation/accumulation } \\
\qquad(-) \quad(+)\end{array}$} \\
\hline & & Date & $\begin{array}{l}\text { Range } \\
\mathrm{mm}\end{array}$ & $\begin{array}{l}\text { Mean } \\
\text { mm }\end{array}$ & $\begin{array}{c}\text { Mean } \\
\text { mm water }\end{array}$ & $\begin{array}{c}\text { Range } \\
\text { mm }\end{array}$ & $\begin{array}{c}\text { Mean } \\
\mathrm{mm}\end{array}$ & $\begin{array}{c}\text { Mean } \\
\text { mm water }\end{array}$ \\
\hline $\begin{array}{l}1959 \\
1960\end{array}$ & $\begin{array}{l}45 \\
45\end{array}$ & $\begin{array}{l}\text { Late June } \\
\text { Late June }\end{array}$ & & $\begin{array}{l}510 \\
780\end{array}$ & $\begin{array}{l}173 \\
255\end{array}$ & & $\begin{array}{r}-122 \\
-76\end{array}$ & $\begin{array}{r}-110 \\
-68\end{array}$ \\
\hline $\left.\begin{array}{l}1961 \\
1962\end{array}\right\}$ & $4^{2}$ & & & & & -90 to - I 010 & -640 & -576 \\
\hline 1963 & $4^{2}$ & 20 June & $4^{10}-1260$ & 810 & $25 \mathrm{I}$ & -140 to +570 & +180 & +117 \\
\hline 1964 & $4^{I}$ & 25 June & $250-1420$ & $55^{\circ}$ & 171 & -270 to +360 & +160 & +104 \\
\hline $\begin{array}{l}1965 \\
1966\end{array}$ & $4^{2}$ & I2 June & $230-900$ & 570 & 177 & +40 to +750 & +310 & +202 \\
\hline $\begin{array}{l}1966 \\
1967\end{array}$ & $\begin{array}{l}4^{2} \\
42\end{array}$ & & & 490 & 152 & $\begin{array}{l}-420 \text { to }+10 \\
-470 \text { to }-30\end{array}$ & $\begin{array}{l}-210 \\
-140\end{array}$ & $\begin{array}{r}-137 \\
-91\end{array}$ \\
\hline $\begin{array}{l}1907 \\
1968\end{array}$ & $\begin{array}{l}42 \\
40\end{array}$ & $\begin{array}{l}\text { 17 June } \\
5 \text { May }\end{array}$ & $\begin{array}{l}330-000 \\
240-1\end{array}$ & 560 & $\begin{array}{l}152 \\
174\end{array}$ & -470 to +170 & -10 & -7 \\
\hline 1969 & 38 & I5 May & $260-720$ & 470 & 146 & & & \\
\hline
\end{tabular}


In computing water equivalents from these data certain assumptions have been made. First, a mean density of $0.3 \mathrm{I} \mathrm{Mg} \mathrm{m}^{-3}$ has been assumed for the spring snow cover, based on the results of pit studies in 1968 and i 969 . It must be remembered, however, that the total accumulation in any year was not measured, since no record is available of snow that fell between May or June and the end of the ablation season. Hence, figures for snow accumulation must be regarded as minima. The limited data cause an obvious discrepancy in the 1965 summer when the net accumulation for the ice rise exceeds the apparent total accumulation by $25 \mathrm{~mm}$ (Table I). Evidently, in this very cool summer there was appreciable snowfall after the middle of June. Secondly, in computing net accumulation which in this area takes the form of superimposed ice or very icy firn, a mean density of $0.65 \mathrm{Mg} \mathrm{m}^{-3}$ has been assumed for the material. The same density has been used for computing the ablation of this material as formed after I 962 , but a density of $0.9 \mathrm{Mg} \mathrm{m}^{-3}$ has been used for the density of the ice melted from the long-standing ablation surface that existed before 1963 .

Table II. Accumulation and ablation on the Ward Hunt Ice Shelf

\begin{tabular}{|c|c|c|c|c|c|c|c|c|c|c|}
\hline \multirow[b]{2}{*}{ Date } & \multicolumn{4}{|c|}{$\begin{array}{l}\text { Ridge poles } \\
\text { Accumulation }\end{array}$} & \multicolumn{4}{|c|}{$\begin{array}{l}\text { Trough poles } \\
\text { Accumulation }\end{array}$} & \multicolumn{2}{|c|}{$\begin{array}{c}\text { All poles } \\
\text { Accumulation }\end{array}$} \\
\hline & $\begin{array}{c}\text { of } \\
\text { poles }\end{array}$ & $\begin{array}{l}\text { Range } \\
\mathrm{mm}\end{array}$ & $\begin{array}{c}\text { Mean } \\
\mathrm{mm}\end{array}$ & $\begin{array}{c}\text { Mean } \\
\text { mm water }\end{array}$ & $\begin{array}{l}\text { of } \\
\text { poles }\end{array}$ & $\begin{array}{l}\text { Range } \\
\mathrm{mm}\end{array}$ & $\begin{array}{l}\text { Mean } \\
\mathrm{mm}\end{array}$ & $\begin{array}{c}\text { Mean } \\
\text { mm water }\end{array}$ & $\begin{array}{l}\text { Mean } \\
\mathrm{mm}\end{array}$ & $\begin{array}{c}\text { Mean } \\
\text { mm water }\end{array}$ \\
\hline $\begin{array}{l}23 \text { June } 1967 \\
13 \text { May r } 968 \\
18 \text { May } 1969\end{array}$ & $\begin{array}{l}18 \\
60 \\
60\end{array}$ & $\begin{array}{l}420-740 \\
270-980 \\
270-630\end{array}$ & $\begin{array}{l}537 \\
560 \\
440\end{array}$ & $\begin{array}{l}166 \\
174 \\
136\end{array}$ & $\begin{array}{r}3 \\
36 \\
38\end{array}$ & $\begin{array}{l}480-690 \\
330-1240 \\
2 \text { 10-9 10 }\end{array}$ & $\begin{array}{l}560 \\
620 \\
480\end{array}$ & $\begin{array}{l}174 \\
192 \\
149\end{array}$ & $\begin{array}{l}540 \\
580 \\
460\end{array}$ & $\begin{array}{l}167 \\
170 \\
143\end{array}$ \\
\hline \multirow[t]{2}{*}{ Summer } & \multicolumn{4}{|c|}{$\underset{(-) \quad(+)}{\mathcal{N e t}}$} & & $\begin{array}{c}\text { ablation/ } \\
(-)\end{array}$ & $\begin{array}{l}\text { Net } \\
\text { accumulat } \\
\qquad(+)\end{array}$ & & \multicolumn{2}{|c|}{ Net ablation } \\
\hline & & $\begin{array}{l}\text { Range } \\
\mathrm{mm}\end{array}$ & $\begin{array}{l}\text { Mean } \\
\mathrm{mm}\end{array}$ & $\begin{array}{c}\text { Mean } \\
\text { mm water }\end{array}$ & & $\begin{array}{l}\text { Range } \\
\mathrm{mm}\end{array}$ & $\begin{array}{l}\text { Mean } \\
\mathrm{mm}\end{array}$ & $\begin{array}{c}\text { Mean } \\
\text { mm water }\end{array}$ & $\begin{array}{c}\text { Mean } \\
\mathrm{mm}\end{array}$ & $\begin{array}{c}\text { Mean } \\
\text { mm water }\end{array}$ \\
\hline 1966 & 18 & -550 to -180 & -310 & -279 & 3 & -220 to -640 & -390 & $-35 \mathrm{I}$ & 320 & 288 \\
\hline 1967 & 60 & -440 to -40 & -250 & -225 & 35 & -750 to -110 & -340 & -306 & 280 & 252 \\
\hline I 968 & 60 & -360 to +150 & -100 & -90 & 34 & -460 to +250 & -130 & -117 & 110 & 99 \\
\hline
\end{tabular}

\section{Analysis}

The data in Tables I and II have been plotted in Figure 2. Since there are no complete meteorological data for Ward Hunt Island for the summers in question, temperature data from Alert, the nearest weather station, have been used to provide an indication of the "warmth" or otherwise of the summers 1959-68. Mean temperatures at Alert for the months of June, July and August, and for the whole summers have been plotted below the massbalance data.

Considering first the ro years' data from the Ward Hunt ice rise, we note: (I) the great range of snow depths measured in the spring, varying by up to $50 \%$ or more about a mean, (2) the similarly great range in net ablation and accumulation, including both ablation and accumulation at different poles in the same season. Snow depths are dependent on wind action and on irregularities of the previous season's ablation surface, which are comparatively large in relation to snow depths of the order of $500 \mathrm{~mm}$. At the same time, the topography of the ice rise, although subdued with an elevation nowhere exceeding $30 \mathrm{~m}$, is such that poles are situated with aspects varying from more or less northerly to more or less southerly and leading to differences in amounts of ablation. The main point emerging from comparison of summer ablation values on the ice rise with the corresponding mean monthly temperatures at Alert is that there is no close correlation. Admittedly, Ward Hunt Island is about $200 \mathrm{~km}$ west-northwest of Alert, so that local variations in the general weather pattern of north-eastern Ellesmere Island may well account for the lack of correlation. But there are two other factors that should be mentioned. The method of calculating mean daily temperatures at Alert (from which the mean monthly temperatures are derived) as $\frac{1}{2}$ (daily maximum plus daily minimum) may not provide the best assessment of an ablation season, as Arnold and MacKay ( I 964) have pointed 
out. Nor in the present case does the use of mean daily maximum temperatures at Alert give any better correlation. Furthermore, any assessment of the ablation season based on temperatures alone ignores the drastic reduction in melting caused by a new cover of snow with its high albedo. In an area where mean summer temperature does not exceed $+3{ }^{\circ} \mathrm{C}$, the small temperature difference that determines whether precipitation falls as rain or snow is very much
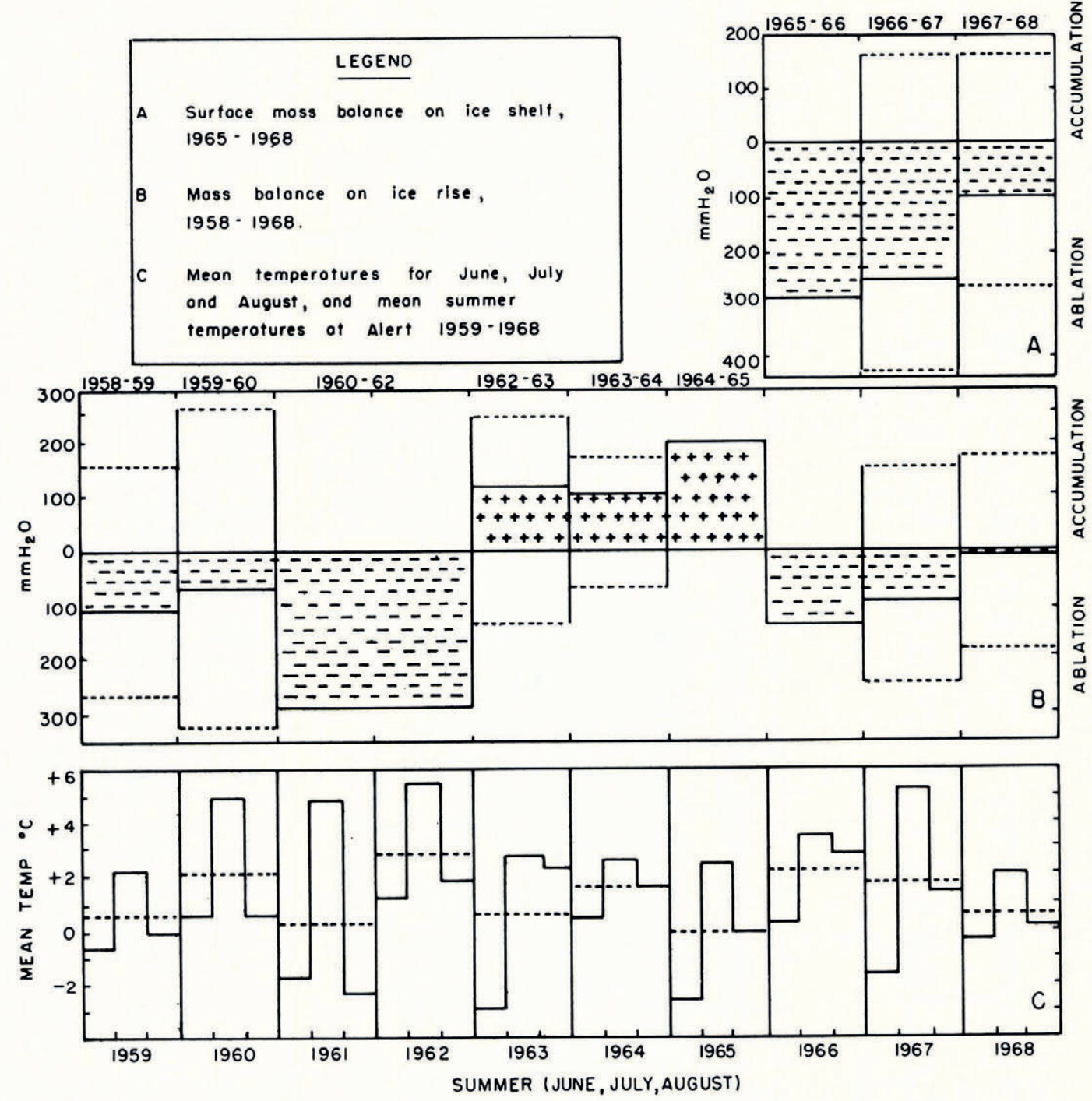

Fig. 2. Mass balance on the Ward Hunt Ice Shelf and ice rise, and mean summer temperatures at Alert.

out of proportion to the effect on ablation at an ice surface (Hattersley-Smith, i96o). The high incidence of low cloud and fog near Ward Hunt Island in summer (Sagar, 1962) is probably a further factor leading to low ablation, as has been suggested by Paterson (1969) in the case of the Meighen Ice Cap, and to distortion of any comparison with the weather at Alert. Since the main purpose in this paper is to present rather than explain the figures for mass balance of the ice near Ward Hunt Island, the comparison with data for Alert will not 
be pressed, nor is it believed for the reasons indicated above that this would be very fruitful. It is sufficient to point out the correlation between more than average warm summers and more than average cold summers in the two areas. Thus the relatively high net ablation on the ice rise for the combined summers $196 \mathrm{I}-62$ agrees with the unusually high temperatures at Alert in the summer of 1962; presumably most of the ablation occurred in 1962. Again, the relatively high net accumulation in 1965 agrees with the low summer temperatures at Alert. But it is anomalous to find that there was net ablation on the ice rise in the summer of 1959 but net accumulation in the summer of 1964 , which was appreciably warmer at Alert.

For the ice-shelf grid in the 3 years $1965^{-68}$ for which records are available, there was a range of snow accumulation both for ridges and troughs similar to that measured on the ice rise (Table II). In I 967 only three trough poles were available for measurement, but in I 968 and 1969 the mean snow depths in the troughs were 60 and $40 \mathrm{~mm}$ greater, respectively, than on the ridges. At the same time net ablation in the troughs was $8 \mathrm{I}$ and $27 \mathrm{~mm}$ greater than on the ridges, with wide variations in both areas. The lakes that occupy the troughs during the ablation season do not drain completely, so that the net ablation measured on the ridges is less than the actual ablation. Nevertheless, the current regime, as shown from only 2 years' useful observations, is competent to preserve the ridge-and-trough topography and even to allow slight deepening of the troughs. It is interesting to find approximately twice as much net ablation on the ice shelf as on the ice rise in the two summers of $1966-67$, although in 1968 , when the ice rise was essentially in balance, there was a deficit of about $100 \mathrm{~kg} \mathrm{~m}^{-2}$ on the ice shelf. From the figures of net accumulation on the ice rise in $1962-65$ (Table I), it seems very likely that there was also net surface gain on the ice shelf during these 3 years. It should be emphasized that the present data refer only to the surface mass balance of the ice shelf; there is no information on whether melting or accretion is taking place at the underside.

\section{Conclusions}

On the ice shelf the years I go6-62 were a period of net surface ablation of the order of metres of water; they were followed by 3 years ( $1962-65)$ of probable positive surface regime, and then by 3 years $\left(1_{9} 5^{-68}\right)$ of net surface ablation totalling $640 \mathrm{~mm}$ water (Table II). On the ice rise the years $1958-68$ were a period of negative mass balance totalling $570 \mathrm{~mm}$ water, but the years $1962-68$ were a period of positive mass balance totalling $190 \mathrm{~mm}$ water (Table I). Quite small deviations from mean summer temperature appear to determine whether the mass balance is positive or negative, and for this reason neither ice rise nor ice shelf should be considered as a relict glacial feature.

\section{Acknowledgements}

We are grateful to Messrs D. J. Finlayson and B. W. Ward for assistance in the field, and to Dr E. Dorrer for the base map (Fig. I). The Director, Meteorological Branch, Department of Transport, Toronto, kindly provided the meteorological data from Alert.

MS. received 29 December 1969

\section{REFERENCES}

Arnold, K. C., and MacKay, D. K. I964. Different methods of calculating mean daily temperatures, their effects on degree-day totals in the high Arctic and their significance to glaciology. Geographical Bulletin
(Ottawa), No. 21, p. 123-29.

Crary, A. P. 1959. Build-up of thick floating ice in Arctic areas. (In Bushnell, V. C., ed. Proceedings of the second annual Arctic planning session, October 1959. Bedford, Mass., Geophysics Research Directorate, Air Force Cambridge Research Center, p. 39-42. (GRD Research Notes, No. 29.))

Hattersley-Smith, G. I 957 . The rolls on the Ellesmere ice shelf. Arctic, Vol. 10, No. I, p. 32-44. 
Hattersley-Smith, G. 196o. Some remarks on glaciers and climate in northern Ellesmere Island. Geografiska Annaler, Vol. 42 , No. I, p. 45-48.

Hattersley-Smith, G. r 963 . The Ward Hunt Ice Shelf: recent changes of the ice front. Fournal of Glaciology, Vol. 4, No. 34, p. $4^{1} 5^{-24}$.

Hattersley-Smith, G., and others. 1955. Northern Ellesmere Island, 1953 and 1954, by G. Hattersley-Smith, [A. P. Crary and R. L. Christie]. Arctic, Vol. 8, No. I, p. 3-36.

Koenig, L. S., and others. 1952. Arctic ice islands, by L. S. Koenig, K. R. Greenaway, Moira Dunbar and G. Hattersley-Smith. Arctic, Vol. 5, No. 2, p. 67-103.

Lister, H. 1962. Heat and mass balance at the surface of the Ward Hunt Ice Shelf, 1960. Arctic Institute of North America. Research Paper No. 19.

Lotz, J. R. 196r. Analysis of meteorological and micrometeorological observations, northern Ellesmere Island, 1959. Arctic Institute of North America. Research Paper No. I2.

Paterson, W. S. B. 1969 . The Meighen Ice Cap, Arctic Canada: accumulation, ablation and flow. Journal of Glaciology, Vol. 8, No. 54, p. 341-52.

Sagar, R. B. 1962. Meteorological and glaciological studies: ice rise station, Ward Hunt Island, May to September 1960. Arctic Institute of North America. Research Paper No. 24. 